\title{
Openness, Bureaucratic Corruption And Public Policy In An Endogenous Growth Model
}

Rangan Gupta, University of Pretoria, South Africa

Emmanuel Ziramba, University of South Africa, South Africa

\begin{abstract}
In this paper, we develop a dynamic general equilibrium overlapping generations monetary endogenous growth model of a financially repressed small open economy characterized by bureaucratic corruption, and, in turn, analyze optimal policy decisions of the government following an increase in the degree of corruption. As suggested in the empirical literature, we find that increases in the degree of corruption should ideally result in an increase in the ratio of seigniorage to total revenue, as an optimal response of the benevolent government. In addition, higher degrees of corruption are also found to be accompanied by higher levels of financial repression.
\end{abstract}

Keywords: Bureaucratic Corruption; Macroeconomic Policy; Openness

\section{INTRODUCTION}

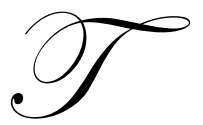

his paper develops a microfounded dynamic general equilibrium overlapping generations' monetary endogenous growth model of a financially repressed small open economy characterized by bureaucratic corruption, and in turn, analyzes optimal policy decisions of the government following an increase in the degree of corruption. Note in a recent paper, Chang et al. (2005), based on a panel of 82 countries, indicate that openness tends to have a bigger impact on growth for less corrupted economies. Given this empirical observation, we, in our theoretical framework, allow bureaucratic corruption to not only adversely affect output directly by reducing the proportion of productive public goods available for production, but also indirectly via a reduction in the efficiency of openness on output.

The motivation for our analysis emanates from a paper by Al-Marhubi (2000). In this study, based on a panel of 41 countries over the period 1980-1995, the author finds a significant positive association between corruption and inflation, thus suggesting that those countries with more corruption experienced higher inflation. The author points out that the link between corruption and inflation was connected to seigniorage. In this backdrop, we in this study, using a panel of 11 African countries ${ }^{1}$ over the period 1995-2006, investigated the relationship between the ratio of seigniorage to total revenue and corruption and found it to be positively and significantly related to corruption $^{2}$ after accounting for country-fixed effects, based on a feasible GLS estimation with cross-section Seemingly Unrelated Regression (SUR) weights to correct for both cross-section heteroskedasticity and contemporaneous correlation. Given these two empirical findings, the relevant question to ask would be, "What is the optimal policy mix between explicit and implicit taxation for the government in the presence of bureaucratic corruption in a small open economy?" Or in other words, we want to investigate whether the increase in the ratio of

\footnotetext{
${ }^{1}$ The countries chosen for our empirical analysis was based on the availability of data, and were namely: Algeria, Congo, Ivory Coast, Egypt, Kenya, Morocco, Senegal, Sierra Leone, South Africa, Tunisia and Zambia. Data on taxes, money growth rates, and total revenue were obtained from the World Bank's World Development Indicators, while, the information on corruption was derived from the World Bank's Governance Indicators database. While, the data on case reserve requirements is obtained from the IMF's International Financial Statistics (IFS) database.

${ }^{2}$ The obtained value for the coefficient on corruption was 0.024 and was statistically significant at the one percent level.
} 
seigniorage to total revenue with higher levels of corruption, as suggested by the empirical evidences, is an optimal outcome of a benevolent government trying to maximize social welfare.

The need to introduce financial repression ${ }^{3}$, modeled through an obligatory "high" reserve deposit ratio requirement that the banks in the economy need to maintain, ${ }^{4}$ in the paper, is mainly to satisfy a second related objective of the paper. Through this study, we also attempt to assay whether there exists a plausible explanation as to why the reserve requirements in some economies are higher than others. Specifically, we analyze whether the "high" reserve requirements in a small open economy characterized by bureaucratic corruption can be a fallout of a welfaremaximizing decision of the government, having access to income taxation and seigniorage as sources of revenue. The hypothesis that bureaucratic corruption might affect the reserve requirements, and hence, the degree of financial repression, simply comes from the two above-mentioned empirical findings indicating the relationship between corruption and seigniorage. Note, with the banks holding cash-reserves, the size of the reserve requirement determines the magnitude of the seigniorage base. In addition, allowing for financial repression to be represented through cash reserve requirements helps us to monetize the endogenous growth model quite easily.

Given that both developed and developing economies resort to financial repression (Espinosa and Yip (1996)), the pertinent question here is, "Why, if at all, would a government want to repress the financial system?" This seems paradoxical, especially when one takes into account the well documented importance of the financial intermediation process on economic activity, mainly via the finance-growth nexus. ${ }^{5}$ Besides, the fact that "high" cash reserve requirements simply enhances the size of the implicit tax base and hence is lucrative for the government to repress the financial system, alternative explanations for causes of financial repression, with varied success, have ranged from inefficient tax systems (Cukierman et al.(1992) and Giovannini and De Melo (1993)) and tax evasion (Roubini and Sala-i-Martin (1995), Gupta (2005, 2006, 2008a) and Gupta and Ziramba (2008)) to the degree of financial development ( Di Giorgio (1999)) and imperfect information and banking crisis (Gupta (2005, 2006)) and, ultimately, as of yet, to currency substitution (Gupta (2008a)). This paper, thus, attempts to add bureaucratic corruption to the already existing wide set of possible explanations for the existence of financial repression besides trying to address the issue of the optimal policy mix of a consolidated government in the presence of bureaucratic corruption.

Given the importance of financial repression, productive public expenditure, and bureaucratic corruption in the growth process of economies, the results of the theoretical model clearly have important policy implications. To the best of our knowledge, this study is the first attempt to analyze the relationship between corruption, openness and public policy, by combining the literatures on endogenous growth, openness and bureaucratic corruption in one framework.

Section 2 outlines the economic environment, while Section 3 defines the equilibrium, Sections 4 and 5, respectively, present the discussion on calibration and the optimal policy decisions of the consolidated government, and Section 6 is the conclusion.

\section{ECONOMIC ENVIRONMENT}

The economy is populated by five types of agents, namely, consumers, banks (financial intermediaries), firms, bureaucrats and an infinitely-lived government. The following subsections lay out the economic environment in detail, by considering each of the agents separately and accounting for the external sector.

\footnotetext{
${ }^{3}$ Note, financial repression can be broadly defined as a set of government legal restrictions, like interest rate ceilings, compulsory credit allocation and high reserve requirements, that generally prevent the financial intermediaries from functioning at their full capacity level. However, given the wave of interest rate deregulation in the 1980s, and removal credit ceiling some years earlier, the major form of financial repression is currently via obligatory reserve requirements (Caprio et al. (2001)).

${ }^{4}$ In this regard, we follow Drazen (1989), Bacchetta and Caminal (1992), Haslag and Hein (1995), Espinosa and Yip (1996), Haslag (1998), Haslag and Koo (1999), Bhattacharya and Haslag (2001), Gupta (2005, 2006, 2008a, 2008b) and Gupta and Ziramba (2008).

${ }^{5}$ See Roubini and Sala-i-Martin (1992), and the references cited there in.
} 


\subsection{Consumers}

The economy is characterized by an infinite sequence of two period lived overlapping generations of consumers. Time is discrete and indexed by $t=1,2, \ldots . N$ people are born at each time point $t \geq 1$. At $t=1$, there exist $N$ people in the economy, called the initial old, who live for only one period. Hereafter $N$ is normalized to 1.

Each agent is endowed with one unit of working time $\left(n_{t}\right)$ when young and is retired when old. They supply this unit of labor inelastically and receives a competitively determined wage of $w_{t}$. It is assumed that agents consume only when old and hence, the net of tax wage earnings are deposited with the financial intermediaries. The proceeds from the bank deposits are used to obtain second period consumption. The consumption bundle comprises of a domestically produced good and an imported foreign good. The utility function is assumed to be separable and additive in the two goods.

Formally, the agent's problem born in period $t$ is as follows:

$\max U=\psi \frac{\left(c_{t+1}\right)^{(1-\sigma)}}{1-\sigma}+(1-\psi) \frac{\left(c_{t+1}^{*}\right)^{(1-\sigma)}}{1-\sigma}$

$p_{t} d_{t}(1-\tau) p_{t} w_{t}$

$$
p_{t+1} c_{t+1}+p_{t+1}^{*} e_{t+1} c_{t+1}^{*}\left(1+i_{d t+1}\right) p_{t} d_{t}
$$

where $U($.$) is the utility function, with the standard assumption of positive and diminishing marginal utilities in$ both goods; $\psi(1-\psi)$ is the weight the consumer assigns to the domestic (foreign) good in the utility function; $c_{t+1}$ and $c_{t+1}^{*}$ are the old age consumption of domestic and foreign good, respectively; $d_{t}$ are the real deposits held in period $t ; \tau_{t}$ is the tax rate at period $t ; p_{t},\left(p_{t+1}^{*}\right)$, is the price of the domestic (foreign) consumption good at period $t ; e_{t+1}$ is the nominal exchange rate at period $t+1 ; i_{d t+1}$ is the nominal interest rate on bank deposits.

Utility maximization is equivalent to maximizing the old-age consumption bundle with respect to $c_{t+1}^{*}$. The maximization problem of the consumer, with $\sigma=1$, yields the following optimal choices:

$d_{t}=(1-\tau) w_{t}$

$c_{t+1}=\psi\left[\left(1+r_{d t+1}\right)(1-\tau)\right] w_{t}$

$c_{t+1}^{*}=(1-\psi)\left[\left(1+r_{d t+1}\right)(1-\tau)\right] w_{t}$

We are assuming that the Purchasing Power parity $(P P P)$ condition, $p=e p^{*}$, holds. Since the foreign price, $p^{*}$, is given to the small open economy, we set it to unity without any loss of generality. This implies that the domestic price level and the nominal exchange rate are synonymous for the model economy with the PPP condition satisfied, i.e., $p_{t}=e_{t}$. Note $\frac{P_{t+1}}{p_{t}}=\pi_{t+1}$ is the gross rate of inflation. 


\subsection{Financial Intermediaries}

The financial intermediaries, in this economy, behave competitively but are subject to cash reserve requirements. In period $t$ banks accept deposits and make their portfolio decision, loans and cash reserves choices, with a goal of maximizing profits. The banks provide a simple pooling function by accumulating deposits of small savers and loaning them out to firms after meeting the cash reserve requirements. Bank deposits are assumed to be one period contracts for simplicity, guaranteeing a nominal interest rate of $i_{d t}$ with a corresponding nominal loan rate of $i_{l t}$. At the end of the period they receive their interest income from the loans made and meet the interest obligations on the deposits. Note the intermediaries are constrained by legal requirements on the choice of their portfolio (that is, reserve requirements), as well as by feasibility. Given such a structure, the real profit of the intermediary can be defined as follows:

$$
\max _{l_{t}, d_{t}, m_{t}} \Pi_{B t}=i_{l t} l_{t}-i_{d t} d_{t}
$$

subject to

$$
l_{t}+m_{t} \leq d_{t}
$$

$m_{t} \geq \gamma d_{t}$

where $\Pi_{B t}$ is the profit of the bank in real terms at period $t ; l_{t}$ is the loans in real terms at period $t$. Equation (8) ensures the feasibility condition, and $m_{t}$ is the banks' holding of fiat money in real terms. The banks are also subject to reserve requirements on cash, given by (9).

The solution to the bank's profit maximization problem results from the zero profit condition and is given by

$i_{L t}(1-\gamma)=i_{d t}$

Simplifying, in equilibrium, the following condition must hold

$$
1+r_{d t}=(1-\gamma)\left(1+r_{L t}\right)+\frac{\gamma}{1+\pi_{t}}
$$

As can be observed from (10) the solution to the bank's problem yields a loan rate higher than the interest rate on the deposits, since reserve requirements tend to induce a wedge between borrowing and lending rates for the financial intermediary.

\subsection{Firms}

All firms are identical and produce a single final good $\left(y_{t}\right)$, which can be allocated to investment demand $\left(i_{k t}\right)$ and consumption goods $\left(c_{t}\right)$. We assume that producers are capable of converting bank loans into fixed capital formation such that: $p_{t} i_{k t}=p_{t} l_{t}$ and $l_{t},\left(\frac{L_{t}}{p_{t}}\right)$ is the loan in real terms. We also assume that the production transformation schedule is linear so that the same technology applies to both capital formation, consumption good and export production, hence, investment, consumption and export goods sell for the same price $p_{t}$. Each firm uses a Cobb-Douglas-type production function as follows: 


$$
y_{t}=A I^{\lambda} k_{t}^{\alpha}\left(\phi n_{t} g_{t}\right)^{1-\alpha}
$$

where $\lambda$ is the effectiveness of openness and is defined as follows, to take account of the fact that corruption affects the marginal product of openness $(\lambda)$, as empirically indicated by Chang et al. (2005):

$$
\lambda=\left[\phi\left(\frac{g_{t}}{w_{t}}\right)\right]^{\eta}
$$

where $y_{t}$ is output; $n_{t}$ is the hours of labor supplied inelastically to production in period $t ; k_{t}$ is the per-firm capital stock in period $t ; g_{t}$ is government expenditure in period $t ; A$ is a positive scalar; $I$ is an index of openness; $\phi$ is the fraction of government expenditure that is productive, or alternatively, it can also be interpreted as an index of corruption, with smaller values indicating a more corrupted economy; $0<\alpha(1-\alpha)<1$, is the elasticity of output with respect to capital (labor), and; $\eta(\geq 0)$ captures the marginal effect of corruption on the marginal product of openness. Note, the production function in (12) is subject to constant returns to scale in $k_{t}$ and $n_{t}$, while, there is increasing returns to scale in all the three inputs taken together. We follow Barro (1990) in assuming that $g$ is a non-rival and non-excludable input in the production process. Each firm takes the level of $g_{t}$ as given while solving its own optimization problem. The production function, thus, exhibits private diminishing returns.

Firms operate in a competitive environment and maximize profit, taking the wage rate, the price of the consumption good, the level of $g_{t}$ and the loan rate as given. We follow Diamond and Yellin (1990) and Chen et al. (2000) in assuming that the goods producer is a residual claimer, i.e., the producer ingests the unsold consumption good, in a way consistent with lifetime maximization of the value of the firms. The ownership assumption avoids unnecessary Arrow-Debreu redistribution from firms to households and simultaneously maintains the general equilibrium nature of the model.

The representative firm at any point in time $t$ maximizes the discounted stream of profit flows subject to the capital evolution and loan constraints. Formally, the dynamic optimization problem of the firm can be summarized as follows:

$$
\begin{aligned}
& \max _{k_{t+1}, n_{t}} \sum_{i=0}^{\infty} \rho^{i}\left[p_{t} y_{t}-p_{t} w_{t} n_{t}-\left(1+i_{L t}\right) L_{t}\right] \\
& k_{t+1} \leq\left(1-\delta_{k}\right) k_{t}+i_{k t} \\
& p_{t} i_{k t} \leq L_{t} \\
& L_{t}\left(1-\gamma_{t}\right) \leq D_{t}
\end{aligned}
$$

where $\rho$ is the firm owners (constant) discount factor, and $\delta_{k}$ is the (constant) rate of capital depreciation. The firm solves the above problem to determine the demand for labor and investment in period $t$, or the gross amount of capital to be carried over to period $t+1$. The firm's problem can be written in the following respective recursive formulation: 
$V\left(k_{t}\right)=\max _{n, k^{\prime}}\left[p_{t} y_{t}-p_{t} w_{t} n_{t}-p_{t}\left(1+i_{L t}\right)\left(k_{t+1}-\left(1-\delta_{k}\right) k_{t}\right)\right]+\rho V\left(k_{t+1}\right)$

The upshot of the above dynamic programming problem are the following respective first order conditions.

$$
\begin{aligned}
& k_{t+1}:\left(1+i_{L t}\right) p_{t}=\rho p_{t+1}\left[A I^{\lambda} \alpha\left(\phi \frac{g_{t+1}}{k_{t+1}}\right)^{1-\alpha}+\left(1+i_{L t+1}\right)\left(1-\delta_{k}\right)\right] \\
& \left(n_{t}\right): A I^{\lambda}(1-\alpha) \phi^{1-\alpha}\left(\frac{g_{t}}{k_{t}}\right) k_{t}=w_{t}
\end{aligned}
$$

Equation (19) provides the condition for the optimal investment decision of the firm. The firm compares the cost of increasing investment in the current period with the future stream of benefits generated from the extra capital invested in the current period. Equation (20) simply states that the firm hires labor up to the point where the marginal product of labor equates the real wage.

\subsection{Bureaucrats}

The bureaucrats are assumed to be risk neutral and they maximize expected profits which are given by

$E\left(\Pi_{B}\right)=q(1-\phi) g_{t}+(1-q)(1-\phi) g_{t}-q \mu g_{t}$

where $q$ is the probability of getting caught which is defined as $q=\frac{1}{2}(1-\phi)^{2}$ with $(1-\phi)$ indicating the proportion of public expenditures that the bureaucrats steal. Note we assume that the chances of getting caught increases as the embezzlements rises, and; $\mu(>1)$ is penalty rate if caught. The optimization problem the bureaucrat essentially implies that the bureaucrat maximizes the expected profit by choosing $(1-\phi)$. Formally, this is given as follows:

$$
\frac{d E\left(\Pi_{B}\right)}{d(1-\phi)}=g_{t}-(1-\phi) g_{t} \mu=0
$$

The solution to the above optimization problem yields:

$$
(1-\phi)=\frac{1}{\mu}
$$

Understandably, the fraction of resources stolen by the bureaucrats is negatively related to the penalty rate. The determination of size of the latter is discussed in the next section.

\subsection{Government and the External Sector}

In this section, we describe the activities of an infinite-lived government. The government spends $g_{t}$. These expenditures are financed by income tax and printing of fiat money. The government has at its disposal two tools of monetary policy, the reserve requirement and the rate of money supply growth, the tax rate and government expenditures are the tools of fiscal policy. Formally, the government's budget constraint at date $t$ can be defined as follows:

$$
p_{t} g_{t}=\tau p_{t} w_{t}+\left[M_{t}-M_{t-1}\right]
$$


where $M_{t}$ is the banks' holdings of fiat money in nominal terms. We assume that money evolves according to the policy rule $M_{t}=\left(1+\theta_{t}\right) M_{t-1}$, where $\theta(>0)$ is the money growth rate. Note, the government also gets revenue from penalties on the corrupt bureaucrats who get caught. Following Del Monte and Papagni (2001), we assume that the government incurs monitoring costs which are equal to the revenue generated from the penalties: $q \mu g_{t}=q c g_{t}$ and hence $\mu=c$.

In the external sector, for simplicity, we assume away capital mobility. Thus, in equilibrium the trade balance is equal to zero. The balance of payments identity of this economy, assuming that $(P P P)$, i.e., $p=e p^{*}$ holds for all $t$, is given by

$$
\begin{aligned}
& x_{t}-c_{t}^{*}=0 \\
& x_{t}=\Omega w_{t} \\
& c_{t}^{*}=\Omega w_{t}
\end{aligned}
$$

Realizing that in steady-state all the real variables grow at the same rate, we ensure that exports and imports are a fixed proportion of income or the wage rate.

\section{EQUILIBRIUM}

A competitive equilibrium for this model economy is a sequence of prices $\left\{p_{t}, e_{t}, i_{d t}, i_{L t}\right\}_{t=0}^{\infty}$, allocations $\left\{c_{t+1}, c_{t+1}^{*}, n_{t}, i_{k t}\right\}_{t=0}^{\infty}$, stocks of financial assets $\left\{m_{t}, d_{t}\right\}_{t=0}^{\infty}$, exogenous sequence of $\left\{p_{t}^{*}\right\}_{t=0}^{\infty}$ and policy variables $\left\{\gamma_{t}, \tau_{t}, \theta_{t}, g_{t}\right\}_{t=0}^{\infty}$ such that:

- $\quad$ Taking, $\tau_{t}, g_{t}, p_{t}, i_{d t+1}, \lambda$ and $w_{t}$, the consumer optimally chooses $c_{t+1}, c_{t+1}^{*}, d_{t}$, such that (2) and (3) hold;

- $\quad$ Banks maximize profits, taking $i_{l t}, i_{d t}$, and $\gamma_{t}$ as given and such that (11) holds;

- The real allocations solve the firm's date- $t$ profit maximization problem, given prices and policy variables, such that (15)-(17) hold;

- $\quad$ The bureaucrats maximize their expected profits such that (23) holds for all $t \geq 0$;

- $\quad$ The money market equilibrium conditions: $m_{t}=\gamma_{t} d_{t}$ is satisfied for all $t_{0}$;

- $\quad$ The loanable funds market equilibrium condition: $p_{t} i_{k t}=\left(1-\gamma_{t}\right) D_{t}$ where the total supply of loans $L_{t}=\left(1-\gamma_{t}\right) D_{t}$ is satisfied for all $t \geq 0$;

- $\quad$ The goods, money, loanable funds, and labor market equilibrium condition is satisfied at all $t \geq 0$;

- The labor market equilibrium condition: $\left(n_{t}\right)^{d}=1$ for all $t \geq 0$;

- $\quad$ The government budget, equation (26) is balanced on a period-by-period basis;

- $\quad$ The equilibrium condition in the external sector requires, equation (27) to hold, along with the PPP condition being satisfied for all $t \geq 0$;

- $\quad d_{t}, m_{t}, i_{d t}, i_{L t}, p_{t}^{*}$ and $p_{t}=e_{t}$ must be positive at all dates. 


\section{CALIBRATION}

In this section, we discuss how we assign values to the parameters of our model, based on a combination of figures from previous studies and those that we calibrate. Following the standard real business cycle literature, we use steady-state conditions to establish parameter values observed in the data. Some parameters are calibrated using world economy data, while others correspond to prevailing values from the literature. This section reveals the general procedures used.

A first set of parameter values is given by numbers usually found in the literature. The following parameter values were chosen initially and the specific source is mentioned in the parentheses given aside, except for the standard ones. These are:

- $\quad \sigma$ : the degree of risk aversion, as stated above, was set to 1 ;

- $\quad \alpha$ : since the production function is Cobb-Douglas, this corresponds to the share of capital in income. The value chosen was of 0.70 (Basu (2001));

- $\quad \delta_{k}$ : the depreciation rate of physical capital was set at 0.05 or 5 percent (Zimmermann (1994));

- $\quad \chi$ : the gross growth rate set equal to 2.5 percent (Basu (2001));

- $\quad \gamma$ : the annual reserve-deposit ratio was fixed at 0.15 (Haslag and Young (1998));

- $\tau$ : tax rate, calculated as the ratio of tax receipts to gross domestic product, was set to 0.25 or 25 percent (Chari et al. (1995));

- $\quad \pi$ : the annual rate of inflation was fixed at 5 percent, and, hence, the gross rate of inflation was $\pi=1.05$ (Basu (2001));

- $\quad i_{L t}$ : the nominal interest rate on loans was set to 0.15 or 15 percent (Gupta (2008a));

- $\quad \beta$ : the discount rate, is set to 0.98 (Chari et al. (1995));

- $\quad \eta$ : defines how the effectiveness of openness on output changes with changes in the level of corruption, and is set to 3 (Chang et al. (2005));

- $\phi$ : the proportion of government expenditure that is productive. We set this at $1,0.5$ and 0.01 for the policy experiments discussed in the next section.

A second set of parameters are are calibrated from the steady-state equations of the model to make them hold exactly: These parameters are:

- $\quad 1+\theta:$ the gross money growth rate is calibrated using the money market equilibrium which implied that $1+\theta=\chi \times \pi$. This resulted in the net money growth rate to be equal to 0.076 or 7.6 percent;

- $\quad \rho:$ the discount factor of the firms is solved to ensure that equation (19) holds and is equal to 0.834;

- $A$ : the value of the production function scalar, is calibrated from the equilibrium conditions to match the growth rate of 2.5 percent and an inflation rate of 5 percent and is equal to 0.718 ;

- $\quad b$ : the ratio of government expenditure to capital which has a value of 0.016 or 1.6 percent, is calibrated from the government budget constraint.

- $\quad I$ : the measure of openness is calculated as ratio of the world exports and imports to world GDP for the year 2005, based on data from the World Bank's World Development Indicators, and has a value of 0.47.

- $\Omega$ : as can be seen from the equilibrium in the external sector, defined by equation (27), the parameter defines the fraction of exports and imports to the wage rate and is half of the openness index, with a value of 0.235 .

\section{OPTIMAL POLICY DECISIONS}

In this section, we analyze the optimal policies for the government in the facing of a rise in bureaucratic corruption. For this purpose, we study the behavior of a social planner who maximizes the utility of all consumers, 
by choosing $\gamma, \tau$ and $\theta$, subject to a set of inequality constraints: $0 \leq \gamma \leq 1, \theta \geq 0$, and $0 \leq \tau \leq 1$, evaluated at the steady state, following changes in $\phi$. The social planner maximizes the discounted stream of life-time consumer utility, which specifically, with the discount rate $0<\beta<1$, is captured by: $W=\sum_{i=0}^{\infty} \beta^{i} U\left(c_{t+1+i}, c_{t+1+i}^{*}\right)$, which, in turn, is equal to: $W=\psi \log [\psi]+(1-\psi) \log [1-\psi]+\log \left[1-\tau_{t}\right]+\log \left[1+r_{d t+1}\right]+\log \left[w_{t}\right]+\frac{\beta}{(1-\beta)^{2}} \log \left[\chi_{t}\right]$

where $\chi_{t}=A I^{\lambda}\left(1-\gamma_{t}\right)\left(1-\tau_{t}\right)(1-\alpha) \phi^{1-\alpha} b^{1-\alpha}+\left(1-\delta_{k}\right), \quad\left(1+r_{d t+1}\right)=(1-\gamma)\left(1+r_{L t+1}\right)+\frac{\gamma}{1+\pi_{t+1}}, \quad b$ $=\left[\tau+\frac{\theta}{1+\theta} \gamma(1-\tau) A I^{\lambda}(1-\alpha) \phi^{(1-\alpha)}\right]^{\frac{1}{\alpha}}$ and $\left(1+r_{L t}\right)=\frac{\rho A I^{\lambda}(\phi b)^{1-\alpha}}{1-\rho\left(1+\pi_{t}\right)\left(1-\delta_{k}\right)}$. We will assume that the government follows time invariant policy rules, which means that the institutionally determined tax rate, $\tau_{t}$, the cash reserve ratio, $\gamma_{t}$, the money growth rate, $\theta_{t}$, the level of government expenditures, $g_{t}$ are constant over time.

We first derive the optimal values of $\gamma, \tau$, and $\theta$ in the cases where $\eta=3$ for $\phi=1$, and then repeat the experiment for $\phi=0.75, \phi=0.5, \phi=0.25$ and $\phi=0.01$. The experiments, thus, tend to capture the effect on the optimal policy decisions of the government as the level of corruption increases, under a situation where corruption affects the marginal product of openness, besides directly affecting output. The results have been reported in Table $1 .{ }^{6}$

Table 1: Optimal Policy Decisions $\eta=3$

\begin{tabular}{|l|c|c|c|c|}
\hline & $\tau^{*}$ & $\theta^{*}$ & $\gamma^{*}$ & $\frac{\text { Seigniorage }}{\text { Revenue }}$ \\
\hline$\phi=1.0$ & 0.4485 & 22.61 & 44.26 & 94.77 \\
\hline$\phi=0.75$ & 0.4476 & 22.22 & 46.97 & 95.00 \\
\hline$\phi=0.5$ & 0.4467 & 21.58 & 51.02 & 95.28 \\
\hline$\phi=0.25$ & 0.3243 & 21.07 & 60.69 & 97.01 \\
\hline$\phi=0.01$ & 0.1293 & 20.17 & 63.04 & 98.79 \\
\hline $\begin{array}{l}\text { (i) Parameters are as defined above. } \\
\text { (ii) All values in percentages. }\end{array}$
\end{tabular}

Based on the results obtained in Table 1, one can draw the following conclusions ${ }^{7}$ :

- Increases (decreases) in the degree of corruption leads the government to resort to reducing (decreasing) taxes and money supply growth rate as an optimal response.

- $\quad$ As a far as the degree of financial repression is concerned, the results indicate that the government should optimally increase the reserve requirements as a response to higher levels of corruption.

- Overall, the ratio of seigniorage to total revenue is found to increase with the degree of corruption.

Intuitively, the obtained results make sense. An increase in the degree of corruption results in the fall in the growth rate due to a decline in the productive effect of the government expenditure, which, in turn, reduces welfare.

${ }^{6}$ Note, the model does not analyze the possibility of transitional dynamics. Here, we are merely interested in figuring out the movements of $\gamma, \tau$ and $\theta$ following a change in $\phi$ across steady-states.

${ }^{7}$ While reading the table, one must be aware that what matters in this simulation exercise is the movements in the policy parameters of the government following increases in the level of bureaucratic corruption, and not the exact values of the parameters per se. 
The government responds by reducing the tax rate, which would boost savings causing higher growth rate and higher welfare. However, a reduction in the tax rate results in the fall of government revenue and tends to have a negative indirect impact on growth and welfare. To restore the size of the government revenue the planner increases seigniorage by increasing the reserve requirement. But, given that increases in the reserve requirement tends to reduce the real interest rate on deposits and, thus, welfare, the government compensates by reducing the money growth rate, hence, increasing the real interest rate, in such a way that the loss in revenue for a reduction in the money growth rate does not reduce growth and affect welfare indirectly. It must, however, be realized that all these changes occur simultaneously and the government chooses the policy instruments taking into account the direct and indirect effects on welfare following an increase in the degree of corruption.

\section{CONCLUSION}

Using a dynamic general equilibrium overlapping generations' monetary endogenous growth model of a financially repressed small open economy characterized by bureaucratic corruption, we analyze the relationship between openness, bureaucratic corruption, and public policies. In this paper, we specifically try and attempt to find what the optimal policies of a benevolent government would be following an increase in the level of bureaucratic corruption, with the latter affecting output not only directly, but also through the effectiveness of openness.

When numerically analyzed for a world economy, the following basic conclusions could be drawn: 1) As suggested in the empirical literature, increases in the degree of corruption should ideally result in an increase in the ratio of seigniorage to total revenue, as an optimal response of the benevolent government and 2) Higher degrees of corruption should be accompanied by higher degrees of financial repression. This paper thus indicates that bureaucratically corrupted economies would tend to rely more on indirect taxation than direct taxation, as this is an optimal response for a benevolent social planner. In the process, the paper provides a theoretical background to the empirical observation of higher corruption resulting in higer seigniorage as a percentage of the total revenue. Finally, we also show that bureaucratic corruption produces a positive relationship with financial repression and hence, can be identified as a possible rational for the latter. By doing so, we add to the list of explanations trying to reason the existence of financial repression.

\section{AUTHOR INFORMATION}

Rangan Gupta, I am currently a Full-Professor at the Department of Economics, University of Pretoria. After having completed my Ph.D. in May 2005 from the Department of Economics, University of Connecticut, I joined the Department of Economics, University of Pretoria, as a Senior Lecturer in August 2005 and got promoted to an Associate Professor in July 2007. I have published in journals such as: Annals of Economics and Finance, Economic Modelling, Economic Notes, International Economic Journal, International Journal of Forecasting, Journal of Developing Areas, Journal of Economic Studies, Journal of Forecasting, Journal of Housing Economics, Journal of Housing Research, etc.

Emmanuel Ziramba is currently a Professor of Economics with the University of South Africa. He joined the University of South Africa as a lecturer on 1 March 2004 and was promoted to senior lecturer with effect from the $1^{\text {st }}$ of January 2008. He has a Ph.D. from the Department of Economics, University of Pretoria. He secured his BSc (Honours) and the MSc degrees from the University of Zimbabwe. He has published a number of papers in peer reviewed local and international journals. His academic interests are mainly International Trade and Finance, Monetary Economics and Public Policy.

\section{REFERENCES}

1. $\quad$ Al-Marhubi, F.A. (2000.) Corruption and inflation. Economics Letters 66, 199-202.

2. Bacchetta, P., and Caminal, R.(Oct. 1992.) Optimal seigniorage and financial liberalization. Journal of International Money and Finance 11(5): 518-538.

3. Barro, R. J. (Oct. 1990.) Government spending in a simple model of endogenous growth. Journal of Political Economy, 98(5, Part - 2): S103-S125.

4. Basu, P. (2001.) Reserve Ratio, Seigniorage and Growth. Journal of Macroeconomics 23(3), 397-416. 
5. Bhattacharya, Joydeep., and Haslag, J. H. (Oct. 2001.) On the use of inflation tax when non-distortionary taxes are available. Review of Economic Dynamics 4(4): 823-841.

6. Caprio, G., Honohan, P., Stiglitz, J. E., 2001. Financial liberalization: How far, how fast? Cambridge University Press, Cambridge, UK.

7. Cuikerman, A., Sebastian, E., and Tabellini, G. (Jun. 1992.) Seigniorage and political instability. America Economic Review 82(3): 537-555.

8. Chang, R., L. Kaltani, N. Loayza. (2005) Openness can be good for growth: The role of policy complementarities. NBER Working Paper Series. Working paper number 11787.

9. Chari, V.V., Manuelli, R.E., and Jones, L.E. (1995.) The Growth Effects of Monetary Policy. Quarterly Review, Federal Reserve Bank of Minneapolis 19(4), 18-32.

10. Chen, B. L., Chiang, Y. Y., and Ping, W. (Jun. 2000.) Credit market imperfections, financial activity and economic growth. Working Paper No. 00-W20, Vanderbilt University.

11. Del Monte, A., and Papagni, E. (2001.) Public Expenditure, corruption, and economic growth: the case of Italy. European Journal of Political Economy 17, 1-16.

12. Di Giorgio, G., 1999. Financial development and reserve requirements. Journal of Banking and Finance 23, 1031-1041.

13. Diamond, P. and Yellin, J. (July 1990.) Inventories and Money Holdings in a Search Economy. Econometrica, 58(4):929-950.

14. Drazen, A. (1989.) Monetary Policy, Seigniorage, and Capital Controls in an Open Economy. In An European Central Bank? (M. de Cecco and A. Giovannini, eds.) Cambridge: Cambridge University Press, pp. 13-52.

15. Espinosa, M., and Yip, C. K. (Jun. 1996.) An endogenous growth model of money, banking, and financial repression. Working Paper No. 96-4, Federal Reserve Bank of Atlanta.

16. Giovanni, A., and De Melo, M. (Sep. 1993.) Government revenue from financial repression. American Economic Review 83(4): 953-963.

17. Gupta, R., (Nov. 2005.) Costly state monitoring and reserve requirements. Annals of Economics and Finance, 6(2): 263-288.

18. Gupta, R., (Feb. 2006.) Asymmetric information, tax evasion and alternative instruments of government revenue. The ICFAI Journal of Monetary Economics, IV(1): 75-89.

19. Gupta, R. (2008a.) Currency substitution and financial repression. Working Paper 06, Department of Economics, University of Pretoria.

20. Gupta, R. (2008b.) Tax evasion and financial repression. Forthcoming Journal of Economics and Business.

21. Gupta, R. and Ziramba, E. (2008.) Tax evasion and financial repression: A reconsideration using endogenous growth models. Working Paper 81, Economic research Southern Africa (ERSA), Department of Economics, University of Cape Town.

22. Haslag, J. H. (Jul. 1998.) Monetary policy, banking and growth. Economic Inquiry XXXVI(3): 489-500.

23. Haslag, J. H., and Hein, S. E. (Apr. 1995.) Does it matter how monetary policy is implemented?. Journal of Monetary Economics 35(2): 359-386.

24. Haslag, J. H., and Koo, J. (1999.) Financial repression, financial development and economic growth. Working Paper No. 99-02, Federal Reserve Bank of Dallas.

25. Haslag, J. H., and Young, E. R. (Jul. 1998.) Money creation, reserve requirements, and seigniorage. Review of Economic Dynamics. 1(3): 677-698.

26. Roubini, N., and Xavier, Sala-i-Martin. (Jul. 1992.) Financial repression and economic growth. Journal of Development Economics 39(1): 5-30.

27. Roubini, N., and X. Sala-i-Martin, (Apr. 1995.) A growth model of inflation, tax evasion, and financial repression. Journal of Monetary Economics, 35(2): 275-301.

28. Zimmermann, C. (Dec. 1994.) Technology innovations and the volatility of output: an international perspective. Working Paper No. 34, CREFE. 
NOTES 